\title{
Simplified method for the cultural diagnosis of gonorrhoea
}

\author{
R. R. WILLCOX AND J. JOHN \\ The Praed St. Clinic, St. Mary's Hospital, London, W.2
}

\section{Description}

A new simplified method which enables a rapid presumptive cultural diagnosis of gonorrhoea-the Ames detection kit or 'Microcult GC'-has been devised. The kit consists of a a small plastic container with a detachable lid, into which are set two buffcoloured squares (approx. $2 \times 2 \mathrm{~cm}$ ) of dessicated modified Thayer-Martin selective medium ${ }^{\star}$ adsorbed into a porous cellulose matrix, the whole being supplied dry and gamma-irradiated in a foil-lined sealed envelope.

After the end of the envelope has been cut off to remove the cassette, the squares are each rehydrated by adding six drops of distilled water, and they are then inoculated with the material under test using a swab or a loop. The lid is replaced and the cassette restored to the foil envelope. A tablet of citric acidsodium bicarbonate mixture is added to the packet before it is sealed by folding and firmly pressing the foil at the open end. The cassette is then incubated at $35-37^{\circ} \mathrm{C}$. for 24 to $48 \mathrm{hrs}$.

To identify Neisseria two strips impregnated with tetramethyl-paraphenelene diamine (oxidase reagent) are provided with each cassette. After $24 \mathrm{hrs}$ one of these is firmly pressed for 3 to $5 \mathrm{sec}$. on one of the squares of medium and if Neisseria is present a blue colour will appear within $30 \mathrm{sec}$. on the buffcoloured surface. The result is then confirmed by a Gram-stained scraping of the blue area. $t$

If the result is negative, the cassette is restored to the incubator and the second square is tested at $48 \mathrm{hrs}$.

\section{Preliminary results}

The kit has been used in 177 male patients before treatment for either gonorrhoea or non-gonococcal urethritis based on a Gram-stained smear of the ^Containing amphotericin B, colistin, lincomycin, and Trimethoprim †To exclude Pseudomonas

Received for publication December 9, 1975

Address for reprints: Dr. R. R. Willcox, M.D., F.R.C.P., as above urethral discharge. In all cases a conventional culture was also made using Thayer-Martin medium which was incubated in the clinic. The results are shown in the Table.

Of the 75 cases initially treated for non-gonococcal urethritis, positive results were obtained by trial culture and confirmed by Gram-stained smear in two and by the routine culture in the same two cases. The trial culture produced one additional apparently positive result which could not be confirmed by Gram stain.

Of the 102 cases treated for gonorrhoea, positive results to the trial culture were obtained in 93 ( 91.2 per cent.) compared with $62(60.8$ per cent.) with conventional cultures which were giving unsatisfactory results at the time. In addition there were six other cases with apparently positive results to the trial culture which could not be confirmed by Gram stain. In neither series did trial cultures, negative at $24 \mathrm{hrs}$, become positive at $48 \mathrm{hrs}$.

\section{Conclusions}

While further work is obviouly needed to define more closely the limitations of the method, it would already appear to have potential for use:

(1) In screening programmes in developing countries at present lacking cultural facilities: if cost precluded continued use it could provide valuable preliminary data defining target groups when planning control programmes;

(2) For general practitioners of all countries in areas remote from laboratories, for which purpose small relatively cheap incubators are available;

(3) To provide a simple means of checking on routine cultural performance in clinics of developed countries.

Thanks are expressed to Messrs. A. J. Moyle, W. Hefferman, A. Whitehead, and A. Cargill of the Praed St. Clinic for their valuable assistance and to Mr. R. Newall of the Ames Company for kindly providing the kits.

TABLE Results obtained with microcult $G C$

\begin{tabular}{|c|c|c|c|c|c|c|c|c|c|}
\hline \multirow[b]{2}{*}{$\begin{array}{l}\text { Urethral Gram } \\
\text { smear }\end{array}$} & \multirow[b]{2}{*}{ Total } & \multicolumn{2}{|c|}{$\begin{array}{l}\text { Trial culture } 24 \text { hrs } \\
(\text { i.e. oxidase }+)\end{array}$} & \multicolumn{2}{|c|}{$\begin{array}{l}\text { Trial culture } 48 \text { hrs } \\
\text { (i.e. oxidase }+)\end{array}$} & \multicolumn{2}{|c|}{$\begin{array}{l}\text { Gram smear from } \\
\text { trial culture }\end{array}$} & \multicolumn{2}{|c|}{ Laboratory culture } \\
\hline & & Pos. & Neg. & Pos. & Neg. & Pos. & Neg. & Pos. & Neg. \\
\hline $\begin{array}{l}\text { Positive } \\
\text { Negative }\end{array}$ & $\begin{array}{r}102 \\
75\end{array}$ & $\begin{array}{r}99 \\
3\end{array}$ & $\begin{array}{r}3 \\
72\end{array}$ & - & $\begin{array}{r}3 \\
72\end{array}$ & $\begin{array}{r}93 \\
2\end{array}$ & $\begin{array}{l}6 \\
1\end{array}$ & $\begin{array}{r}62 \\
2\end{array}$ & $\begin{array}{l}40 \\
73\end{array}$ \\
\hline Total & 177 & 102 & 75 & - & 75 & 95 & 7 & 64 & 113 \\
\hline
\end{tabular}

